\title{
Semantics of Dance and Symbolic Plastic Movements in Tuvan Ceremonial System
}

\author{
Sanchay Choygan* \\ Tuvan State University \\ 36 Lenin Str., Kyzyl, Republic Tuva, 667000, Russia
}

Received 15.09.2016, received in revised form 29.06.2017, accepted 07.07.2017

The article considers the Tuvans' perception of dance. It analyses linguistic functioning of the words denoting dance and the notions associated with it. In Tuvan language, the concept of dance bears semantics of an ancient cult. It is stated that traditionally, the Tuvans perceived dance as a part of their ceremonial and ritual system.

Keywords: saltation, dance, shaman, sam, tsam, khamnaarak, devig, symbolic movement.

DOI: 10.17516/1997-1370-0109.

Research area: theory and history of culture.

As the foundation of dance, saltation was an integral part of ceremonial ritual of the Tuvans. Despite the discussion on the absence of dance culture in the nomadic nations' world, some examples of ancient dance still live in Tuva: khamnyn samy as the shaman's saltation, devig as a ritual dance of the men's contest, tsam or sam as a Buddhist miracle play with large-scale theatrical scenes played by actors wearing masks. There is also an opinion that Tuvan language has no equivalent to the word dance (Ondar, 2012: 90). This study is an attempt to consider some dance-related notions and to find some kinetic semantics in the traditional dance culture of the Tuvans.

In Tuvan language, the meaning of the word samnaash "eagle feather" originated from the word sam "dance" (Tolkovyy slovar'..., 2011: 631, 634). It is metonymic, for the word is related to the shamanistic ritual and has direct connection to the ceremonial actions of the shaman. Eagle feathers, or samnaash, were sawn on the ceremonial costume and the head dress the shaman wore during the ritual. Similarly, from the word sam the word samnaar "to dance" bearing several meanings was derived. First of all, it is used speaking of animals, describing the way they run, play and jump. Secondly, it also means to "jump of joy". Thirdly, samnaar means "to run before flying, flapping wings" (about birds). Moreover, the ritual dance performed during national wrestling (khuresh) competitions is also called samnaar. Samnaar also stands for the pantomime-dance performed by Buddhist monks wearing masks. And, finally, samnaar is a name of shaman's saltation (Tolkovyy slovar'..., 2011: 633).

It is worth noticing that I.O. Ondar also presents several words applicable to the notion

(c) Siberian Federal University. All rights reserved

* Corresponding author E-mail address: choykasanchai@mail.ru 
of a Tuvan dance. In the present article, we considered the definitions of dance related to ceremonial and ritual practice.

Therefore, in the sign system of the shaman cult an eagle feather is a magic symbol. The word samnaash is related to the perception of shaman's actions. Shaman accompanies his ritual performance with some plastic movements, similarly to the actors of tsam Buddhist miracleplay performing their dance as a part of a large religious mass. Samnaash are eagle feathers sawn on the ceremonial gown the shaman wore during the ritual. The word sam has established in the language as a dance the Tuvans know as a part of the shaman's magic performance. It means that samnaar "jump, spin, hop, do various movements during the shamanistic ritual" denotes a plastic act, which is a dance (Tolkovyy slovar'..., 2011: 633). Therefore, samnaash are the feathers used for the shaman's ritual attire.

Interestingly, the word khamnaarak "lark" has a common root with the word kham "shaman" (Tuvinsko-russkiy slovar', 1955: 448). In Tuvan language, the word khamnaarak (khamnay aarak) "lark" is understood as "similar to shaman's saltation". The bird khamnaarak "lark" jumps and spins around a female during mating, like a shaman performing his ritual dance. Similarly, the word khamnaarak has another meaning of "spinning top" (Tuvinsko-russkiy slovar', 1955: 449). Here, to our mind, similarly to the word samnaash, the meaning of the word khamnaarak firmly preserves the meaning of a shaman's ritual. Moreover, the authors of the etymology dictionary of Turkic language suggest that the analysis of words derived from $\mathrm{kam}$ (kham) reveals an older meaning of this Turkic word, such as khamna in Yakut dialect: "start one's way", which, according to the authors, is a euphemism for performing a shamanistic ritual. E.K. Pekarsky points out such meanings as "move, wiggle, walk, start, vibrate, rock, tremble (shudder)", and compares Yakut verbal stem to Turkic khamna "float in the air" (speaking of a bird). The authors of the dictionary also explain: "If we consider that the verbs with -la ending typically have the meaning "to perform the action denoted by the deriving stem", then in Khakass language khamna "perform a shamanistic ritual" and its equivalents are based on the deriving stem kham "shaman's action". Kam and kamla denote ritual actions of the shaman, the distinctive features of which, evidently, are also reflected in Yakut khamna "to perform shamanistic ritual", an archaic word meaning typical movements of the shaman dance (Levitskaia et al., 1997: 241). It is worth noticing, that the word khamna is translated from Tuvan also as "to perform shamanistic ritual".

Further, let's analyse an example from a Tuvan folk fairy tale: Samnaan duruyaa deg salbaranaynyp chorup-turlar evespe "Like dancing cranes they skipped". Here is another example from a Tuvan folk fairy tale: Chanagashool totpaan bodu orta todup, saaskan kezhi chagyzy-bile salbaranaynyp deshkilep... "Sated, Chanagash-ool in his magpie-skin coat burst into a hopping dance..." These examples are remarkable for the fact that the word salbaranaynyp expresses an attribute of dance. In the first example, samnaan salbaranaynup (samnap "dancing"), and in the second salbaranaynyp deshkilep (devip "jumping dance") the word salbaranaynyr means "move, vibrate, weave" (Tolkovyy slovar'..., 2011: 622). Consequently, in combination with devip "saltation" salbaranaynyr means a dance, just like combined with samnaan "dancing", salbaranaynyr also, to our mind, denotes a dance. In this case we may speak of existence of "animal" terminology in Tuvan cultural tradition and the underlying association of gesture and move with totemism (Freidenberg, 1998).

In Yakut dancing terminology, there is a name of an ancient ceremonial round 
dance similar to Tuvan salbaranaynyr: that is sel'bireske dance. The dancers imitate moves of a horse. According to N.A. Struchkova, imitation of a horse expresses the idea of the Sun associated with a celestial animal (Struchkova, 2000).

But let us return to the word khamnaarak "whip-top, to spin"; as we know, any spinning object has an axis, or a centre. The word denotes a figure, a circle, which is a solar symbol. While a male dances around a female, it also acts as a centre for the action. Semantics of a circle is repeated in the action (Sanchay, 2016: 52). The centre of it is a sacred symbol, and the kinetics of the ancient men's dance called devig proves it, as the dance finishes with an essential move around the circle. In this context, the image of the worshipped object is discreetly conventional, the kinetic element of the ritual is an acting circle, and the final part of devig is a move around. It is also worth noticing that the Tuvan deviir "saltate" may have a more ancient form. Etymology of the word devir is explained as "spin, turn, twist", with the key meaning of a circular movement (Levitskaia et al. 1980: 173). Obviously, the origin of devir should also be associated with the solar cult (Sanchay, Kukhta, 2015: 37). On this basis we may suggest that the word devi (noun) retains the formula of ancient worship, which metaphorically repeats the image repeated in a circular move, an essential element of the wrestlers' dancing ritual (Sanchay, 2016: 60). The meaning of the word devig (noun) "to perform a dance during khuresh national wrestling" in the dictionary by B.I. Tatarintsev is accompanied with the following remark: "The verb may be compared to Turkic dep- tep- 'to kick, to fling, to stamp'... and Tuvan tep- meaning 'to dance, saltate"' (Tatarintsev, 2002: 114). Remarkably, N.A. Struchkova associates the Yakut tepsen with horse gush (Struchkova, 2000). Therefore, in the word devig comparable to Old Turkic dep- tep- "kick, fling, stamp", Tuvan tep, tever- "kick, stump, hit with a foot" we should find the root of the notion of dance and saltation. In the present case "stamping with feet" means imitation of stamping moves of sacred animals. In this regard, it is worth noticing that there is a colloquial expression chaza tever, which means "to dance well", or, literally, "stump it" in the meaning "to do tapping" (Tuvinsko-russkiy slovar', 1955: 392).

Researchers of Siberian and North Asian round dances in the traditional ceremonial system describe some sacred attributes. It is a wellknown fact "that Turkic and Mongolian nations closely associated the horse cult with the cult of the World Tree" (Dashieva, 2007). In Yakut culture, a similar sacred vertical was symbolized with a tethering post around which the roundelays were performed, to make contact with supreme gods. In Buryat ceremonial culture, a similar divine vertical was a mount around which the yokhor roundelay was performed. At that, in the final part of the dance the participants had to look up, i.e. to jump. To our mind, the vertical in devig ritual dance is conventional. Devig stands for initiation, worship, desire to be like a bird with wings, at the end of which an essential ritual of "feeding" the deity is performed, by throwing ak chem (white food) up (Sanchay, 2014). Unlike the Buryat yokhor, and Yakut osoukhay, developed like a collective ritual roundelay, Tuvan devig had traditionally formed as a solo dance, a ritual address of an individual representative of the genus. N.A. Struchkova remarks, that the kettle breeder nations' roundelay dances performed as closed circles symbolize several motives at the same time. As a kinetic text, devig may also be regarded as a representation of several motives: aspiration to perform a flight - a sacral vertical, a round dance - the motive of purification, a solar dance - the motive of adoration, imitation of a worshipped deity - imitation of deities, throwing white food - motive of addressing the deity with the request for good luck. 
Thus, according to the aforesaid, the terms of tep and devi, "saltation", are, to our mind, more ancient than the similar notions of samnaar, sam, which came to the language together with Buddhism. The semantics of the words tep and devi revealed some ultimate ancient forms of plastics, the motives of worshipping the ancient deities. The definitions of the Tuvan kham, the bird name khamnaarak, the verb khamna and the Yakut khimna, and, indirectly, the word salbaranaynyr, comparable to the Yakut name of ancient dance sel'bireske, point at the following:
1) presence of the "animal" dance terminology in Tuvan language, which proves connection of gesture and plastics to ancient totemic world outlook; 2) the plastic act of the shaman as a reflection of sacral perception of dance and saltation; 3) cultural unity of plastic mythologic concepts of the kettle breeding nations of the past. To our mind, the semantics of the studied notions of dance express dancing and saltation acts that manifest themselves in the symbolic plastic moves, embodying a complex of ancient cults and mythological concepts.

\section{References}

Dashieva, L.D. (2007). Buriatskiy krugovoy tanets yokhor: istoriko-etnograficheskiy, ladovyy, ritmicheskiy aspekty [Buryat round dance yokhor: historical-ethnographic, harmonic, rhythmic aspects], Diss. ... of the Candidate of Arts. Novosibirsk State Conservatory (Academy) named after M.I. Glinka. Novosibirsk, 268 p.

Freidenberg, O.M. (1998). Mif i literatura drevnosti, 2-e izd. [Myth and literature of antiquity]. Vostochnaia literatura, $799 \mathrm{p}$.

Levitskaia, L.S., Dybo, A.V., Rassadin, V.I. (1997). Etimologicheskiy slovar' tiurkskikh iazykov. Obshchetiurkskie i mezhtiurkskie leksicheskie osnovy na bukvy "- $K$ ” “-K” [Etymology dictionary of Turkic languages. Common Turkic and inter-Turkic lexical stems on the letters "-K” "-K”], available at: http://altaica.r2u/LIBRARY/edtl.php

Ondar, I.O. (2012). Nachal'nyy etap v istorii khoreograficheskogo obrazovaniia v Tuve [The initial stage in the history of choreographic education in Tuva], In Kul'tura Tuvy: proshloe i nastoiashchee [Culture of Tuva: past and present], 90-93.

Sanchay, Ch. (2014). Tanets orla - dukhovno-khudozhestvennoe nasledie tuvinskogo naroda [The Eagle dance - spiritual and artistic heritage of the Tuvan people], In Novye issledovaniia Tuvy [New research of Tuva], 1.

Sanchay, Ch. (2016a). Kul'turnye predposylki vozniknoveniia tuvinskogo khorovodnogo tantsa Cheler-oi [Cultural background of the appearance of Tuvan circle dance Cheler-oi], In Sovremennye gumanitarnye issledovaniia [Modern Humanitarian Studies], 3, 52-56.

Sanchay, Ch. (2016b). Simvolicheskaia plastika v tantseval'noy kul'ture tuvintsev [Symbolic plastics in the Tuvan dance culture], In Aktual'nye problemy issledovaniia etno-ekologicheskikh $i$ etnokul'turnykh traditsii narodov Saiano-Altaia [Actual problems of research of ethno-ecological and ethno-cultural traditions of the peoples of Sayano-Altai], 60-61.

Sanchay, Ch., Kukhta, M.S. (2015). Istoki tuvinskoy khoreografii [Sources of Tuvan choreography], In Sovremennye gumanitarnye issledovaniia [Modern Humanitarian Studies], 3, 37-41.

Struchkova, N.A. (2000). Semantika osnovnykh dvizheniy iakutskogo khorovodnogo tantsa osuokhay [Semantics of the main movements of the Yakut circle dance osuokhay], Diss.... of Candidate of History, Yakut State University named after M.K. Ammosov. Yakutsk, 188 p. 
Tatarintsev, B.I. (2002). Etimologicheskiy slovar' tuvinskogo iazyka. T. II. [Etymology dictionary of Tuvan language, 2]. Novosibirsk, 114-173.

Tolkovyy slovar' tuvinskogo iazyka, t. II [Definition dictionary of Tuvan language, vol. 2] (2011). Novosibirsk, Nauka, 634, 631, 622.

Tuvinsko-russkiy slovar' [Tuvan-Russian dictionary] (1955). State Publishing House of Foreign and National Dictionaries, 448, 449, 392.

\section{Семантика танца и символическая пластика \\ в обрядовой системе тувинцев}

Ч. Санчай

Тувинский государственный университет Россия, 667000, Республика Тыва, Кызылл, ул. Ленина, 36

\footnotetext{
В статье рассмотрены представления тувинцев о танце. Составлен анализ бытования в языке слов, обозначающих «танецџ» и понятий, связанных с ним. В тувинском языке понятие о танце имеет семантику древнего культа. Установлено, что в традиционном представлении тувинцев танец входил в комплекс обрядово-ритуальной системь.

Ключевые слова: пляска, танец, шаман, сам, иам, хамнаарак, девиг, символическая пластика. Научная специальность: 24.00.01 - теория и история культуры.
} 